\title{
THE INFLUENCE OF THE DEBT TO EQUITY RATIO, INVENTORY TURN OVER, AND CURRENT RATIO AGAINST THE RETURN ON EQUITY IN THE PHARMACEUTICAL SECTOR COMPANIES
}

\author{
M. Firza Alpi \\ Fakultas Ekonomi dan Bisnis UniversitasMuhammadiyah Sumatera Utara \\ Muhammadfirzaalpi@gmail.com
}

\begin{abstract}
The purpose of this research is to find out and analysis the influence between the Debt to Equity Ratio, Inventory Turn Over Ratio against and Current Return on Equity well in partial or simultaneously. This research was conducted on the pharmaceutical sector companies were listed on the Indonesia stock exchange. The approach used in this study is Associative and quantitative approach. The number of population at the pharmaceutical sector are 10 companies and samples used as many as 8 companies. Independent variables used in this study consists of a Debt to Equity Ratio (DER), Inventory Turn Over (ITO) and the Current Ratio (CR), and the dependent variable i.e., Return On Equity (ROE). The technique of data collection in this study by using the techniques of documentation. Technique of data analysis in this study using Multiple Linear Regression, Hypothesis Testing, and the coefficient of Determination with a level of significance of 5\%. Data processing in this research using SPSS software programs (Statistics Package for The Social Science) version of 20.00. The results of this research show that the partially Debt to Equity Ratio not effect on Return On Equity, as a partial Inventory Turn Over effect on Return On Equity, as a partial Current Ratio effect on Return On Equity simultaneously, the Debt to Equity Ratio (DER), Inventory Turn Over (ITO) and the Current Ratio (CR) effect significantly to Return On Equity $(R O E)$.
\end{abstract}

Keywords: Debt to Equity Ratio, Inventory Turn Over, Current Ratio, Return on Equity.

\section{INTRODUCTION}

Profits or profit is one of the main objectives of the establishment of any business entity. Without getting profit, the company cannot meet other purposes namely continuous growth and social responsibility. The main aims of profit of the company is the sale of goods or services. The greater the volume of sales of goods and services, then the profits generated by the company also will be even greater. The company's survival is influenced by many things, among others, the profitability of the company itself. The importance of profitability can be seen by considering the impact that comes from the inability of the company in getting maximum profits to support its operational activities. How to take into account the profitability is varied and depends on profit and assets or capital that will be compared to each other. One way to calculate profitability is Return On Equity (ROE).

Return on Equity is a profitability ratio of part in analyzing the financial statements over the company's financial performance reports. According to Brigham and Houston (2012, p. 149) Return on Equity is the return on equity ratio i.e. ordinary net profit against ordinary equity or measure the return on investment of ordinary shareholders. In this case the shareholders expect improvement in return on capital shareholders and attract new investors to invest their funds. Many factors - factors that affect the Return on Equity (return on capital results) whom Debt to Equity Ratio (debt to capital), Inventory Turn Over (inventory turnover), and the Current Ratio (current ratio).

Debt to Equity Ratio is a ratio used to measure how big a debt burden that should be borne by the company in order fulfillment of capital. According to Cashmere (2012, p. 157) Debt to Equity Ratio is a ratio used to assess the debt with equity, this ratio is sought by way of compare between the entire debt includes debt smoothly with the rest of the equity. The greater the total debt compared to equity total will show the greater dependency of the company towards outsiders. This will impact declining returns on capital (ROE) used to cover some or all of the debt - debt either short-term or long-term. Large debts will have an impact on financial risk which must be borne by the company or burdened with interest payments in large numbers. 
But when the loans yield funds are used efficiently and effectively then this will provide a great opportunity for companies to increase profits.

Besides knowing Debt to Equity Ratio of the company need to know Inventory Turn Over (inventory turnover). Inventory is the elements of the current assets is an active element in the operations of a company that continuously retrieved, modified and then sold to consumers. According to Cashmere (2012, p. 180 ) inventory turnover is used to measure the number of times the funding that was planted in the inventory is spinning in one period.

Working capital that is embedded in a long period of time can give direct effect to the profit of the company. This is due to the problem of the determination of the allocation of capital in inventory. According to Arwana (2009, p. 69) investment in inventory problem is a problem of active spending; as with any investments in assets-other assets.

The determination of the proper capital allocation will accelerate cash refund. The higher the level of inventory turnover, the amount of working capital required will be even lower. In addition to knowing the Debt to Equity Ratio and Inventory Turn Over, the company must also find out the Current Ratio (current ratio). Current Ratio is the company's ability to meet obligations or to pay short-term debt. According to Hery (2014, p. 152) Current Ratio is a ratio used to measure a company's ability to meet short-term obligations that are maturing soon using total assets smoothly.

The company is able to meet its assessed as a liquid, the Quantity ratio is often regarded as a measure of good or satisfactory level of liquidity of a company. But when the number ratio too high then it means there are a lot of funds that are embedded in working capital that does not generate profits

\section{LITERATURE REVIEW}

\section{Return On Equity}

Return on Equity that is the ratio between the earnings after taxes to the total own capital (Equity) of capital deposit owners. The higher the Return on Equity shows the more efficient companies in managing their own capital to generate profits/net profit. This ratio is used to measure the rate of return the company or company's effectiveness in generating profits by leveraging the equity owned by the company.

Return on Equity is a profitability ratio of part in analyzing the financial statements over the company's financial performance reports. According to Brigham and Houston (2012, p. 149) "Return on Equity is net profit ratio against ordinary equity or measure the return on investment of ordinary shareholders".

While according to Harahap (2015, p. 305) "Return On Equity shows how many percent gained net profit when measured from capital owners. The greater the more good ". From the definition above it can be concluded that with a Return On Equity of the company could show his ability to generate profit from capital owned by the company. ROE is affected by three factors as expressed by Hani (2015, p. 120) is as follows: 1) Sales Volume, 2) capital structure, 3) and structure debt.As for the formula to find the Return On Equity according to Cashmere (2012, p. 204) are as follows:

Return On Equity = Earning After Interest and Tax Equity

The results of the Return On equity or return on Equity or earnings ratios of capital is itself a measure of the ratio of net income and capital on its own. The higher this ratio is, the better it will be. This means that the position of the owner of the company grew stronger, and vice versa.

\section{Debt to Equity Ratio}

Debt to Equity Ratio is a ratio used to measure comparison between debt with equity in funding companies and shows its own capital to meet these obligations. According to Hani (2015, p. 124) "Debt to Equity Ratio is showing how much each part of its own capital was made rupiah guarantees for the entire debt. The higher this ratio means the higher amount of funds from outside the secured amount of capital on its own ".

While according to Cashmere (2012, p. 157) "Debt to Equity Ratio is a ratio used to assess the debt with equity, this ratio is sought by way of compare between the entire debt includes debt smoothly 
with the rest of the equity". Based on the description above, it can be concluded that the Debt to Equity Ratio is a comparison of capital with a loan that can serve as a guarantee of the company to borrow.

DER influenced by 6 factors such as expressed by Sudana (2011, p. 162) is as follows: 1) the growth rate of sales, 2") sales Stability, 3) industry Characteristics, 4) structure of assets, the company's management Attitude) 5,6) the attitude of the the lender.

According to Hani (2015, p. 124) Debt to Equity Ratio can be calculated with the formula as berikut: Debt to Equity Ratio = Total Liabilitas Total Equity

\section{Inventory Turn Over}

Inventory turnover ratio measures the efficiency of the management of inventory items. This ratio to assess operational efficiency which shows how good the management control on capital stock. According to Arwana (2009, p. 334) "Inventory Turn Over indicates the ability of the Fund that are embedded in a rotating inventory within a certain period, or the liquidity of the inventory and the tendency for the presence of overstock".The company turnover high build-up, giving an indication that the company is its efficiency in managing inventory. According to Hani (2014, p. 44), "inventory of assets is that will directly impact the calculation of the profit because the value of the inventory is the basis of staple production pricing or cost of goods sold". While according to Cashmere (2012, p. 180) "inventory turnover ratio is used to measure the number of times the funding that was planted in stock (inventory) is spinning in one period. The smaller this ratio, the more is not good and vice versa. "From the above it can be concluded that the sense of rotation of the inventory shows how inventory is managed and sold in one period to generate profit for the company.According to Sudana (2011, p. 230) as for the factors that influence Inventory Turn Over is as follows: 1) Request supplies, 2) Lead time, 3) Costs were running out of supplies, 4) storage charges for additional supplies.According to Sudana (2011, p. 21) to find the Inventory Turn Over can be measured in the following way:

Inventory Turn Over $=\quad$ Sales Inventory

The higher this ratio means more effective and efficient management of inventory conducted by the management of the company to generate sales, and vice versa.

\section{Current Ratio}

Current Ratio is the company's ability to meet obligations or pay for short-term debt by comparing between current assets with debt smoothly as a gauge of liquidity of a company. If the company is able to meet its obligations, then the company is rated as a liquid, but if the company is unable to meet its obligations then the company rated as a company ilikuid. According to Hery (2014, p. 152) "Current Ratio is a ratio used to measure a company's ability to meet short-term obligations that are maturing soon using total assets smoothly available".

While according to Munawir (2014, p. 73) "Current too high Ratio indicates an excess of cash money or other current assets compared with the present or the required level of liquidity is lower than current assets and vice versa".In practice, the standards of the current ratio is $200 \%$ or 2:1. Quantity ratio is often regarded as a measure of good or satisfactory level of liquidity of a company. That is, with the results of the calculation of the ratio of a company, it can already be said to be in a secure position for the short term. But when the number ratio too high then it means there are a lot of funds that are embedded in working capital that does not turn a profit.

According to Arwana (2009, p. 28) factors that affect the Current Ratio is as follows: 1) Sold fixed assets, 2) Get additional capital themselves, 3) get additional long-term debt.According to Fahmi (2015, p. 66) Current Ratio can be calculated using the formula:

Current Ratio $=$ Current Asset Current Liabilities

Quantity ratio is often regarded as a measure of good or satisfactory level of liquidity of a company. But when the number ratio too high then it means there are a lot of funds that are embedded in working capital that does not turn a profit. 


\section{FRAMEWORK CONCEPT}

\section{The influence of the Debt to Equity Ratio against the Return On Equity}

According to Cashmere (2012, p. 158) the greater the ratio, the more unfortunate because it will be even greater risk borne over the failures that may occur in the company. From the above it can be concluded that the theory of the high value of the Debt to Equity Ratio of a company, then the company's Return On Equity will decline. This is due to the amount of profit earned will be used to pay the interest charges on loans committed

companies. But if the company is able to manage its business to its full potential then it can boost corporate profits. Because the loans were used to boost production and expand its sales distribution area. Thus the Debt to Equity Ratio will affect the Return On Equity of the company. This is in line with the research Hantono (2015) stating that the Debt to Equity Ratio effect significantly to Return On Equity.

\section{The Influence Of Inventory Turn Over Against The Return On Equity}

According to Cashmere (2012, p. 180) inventory turnover ratio is used to measure the number of times the funding that was planted in the inventory is spinning in one period. From the above it can be concluded that the theory of the increasing Inventory Turn Over a company, then the faster return of funds that are embedded in the inventory. As a result, the profit obtained will be increased. The large number of profit earned will raise the level of profitability of the company. This means companies either in using ekuitasnya to generate a profit. Thus the Inventory Turn Over will affect the Return On Equity of the company. This is in line with the research Jufrizen (2015) which stated that the Inventory Turn Over have significant influence towards Return On Equity.

\section{The Influence Of Current Ratio Against The Return On Equity}

According to Hery (2014, p. 152) Current Ratio is a ratio used to measure a company's ability to meet shortterm obligations that are maturing soon using total assets smoothly. While according to Munawir (2014, p. 73) Current Ratio is too high indicating an excess of cash money or other current assets compared with the present or the required level of liquidity is lower than current assets and vice versa. From the above it can be concluded that the theory of quantity ratio is often regarded as a measure of good or satisfactory level of liquidity of a company. But when the number ratio too high then it means there are a lot of funds that are embedded in working capital that does not turn a profit. This excess will certainly lose the opportunity to obtain an advantage. Thus the Current Ratio will affect the Return On Equity of the company. This is in line with the research Novianti (2015) which States that the Current Ratio has a significant influence against the Return On Equity.

\section{The influence of the Debt To Equity Ratio, Inventory Turn Over Ratio against the Current, and Return On Equity}

Return On Equity is the ratio to measure the company's ability in seeking advantages with its own capital. The most important element is the profit in order for the continuation of the company assured. Every effort always give priority to profits in the company's purpose. To achieve the purpose of the company is then necessary management processes are effective and efficient. Debt to Equity Ratio is a ratio used to measure how big a debt burden that should be borne by the company in order fulfillment of capital. The greater the total debt compared to equity total will show the greater dependency of the company towards outsiders. This will impact declining returns on capital (ROE) used to cover some or all of the debt - debt either shortterm or long-term.

Inventory is the elements of the current assets is an active element in the operations of a company that continuously retrieved, modified and then sold. The higher the value of the Inventory Turn Over then 
the faster return of funds that are embedded in the inventory. As a result, the profit obtained will be increased. The large number of profit earned will raise the level of profitability of the company. This means companies either in using ekuitinya to generate a profit.

Current Ratio is the company's ability to meet obligations or pay for short-term debt by comparing between current assets with debt smoothly as a gauge of liquidity of a company. If the company is able to meet its obligations, then the company is rated as a liquid, but if the company is unable to meet its obligations then the company rated as a company illiquid. Quantity ratio is often regarded as a measure of good or satisfactory level of liquidity of a company. But when the number ratio too high then it means there are a lot of funds that are embedded in working capital that does not turn a profit. This excess naturally lowers the chance of a profit.

\section{RESEARCH METHODS}

\section{Research Approach}

It is associative research aims to know the influence between two or more variables. This study uses secondary data that is empirical, where data are obtained from the document by way of browsing on the Indonesia Stock Exchange's official website. While the research approach used is a quantitative approach, where this approach is based on testing and penganalisisan theories compiled from a variety of variables, measurement involving numbers, and analyzed using the statistical procedure.

\section{Operational Definitions Of Variables}

Based on the problem and hypothesis to be tested, then the variables examined in this study is free/Variable independent variable $(\mathrm{X})$ and the dependent Variable/(Y).

\section{Dependent Variable}

The dependent variable is the variable that is described or affected due to the variable free. According to Sugiyono (2012, p. 59) the dependent variable is the variable that is affected or become due, because of the free variables. The dependent variable in this study is a Return On Equity of any Pharmaceutical Sector Companies in Indonesia stock exchange selected as samples.

According to Hery (a 2015, p. 517) Return On Equity is the ratio that indicates the result (return) for the use of the equity of the company in creating a net profit. In other words, this ratio is used to measure the extent of the amount of net income to be generated from every rupiah of funds that are embedded in the total equity.

\section{Independent Variable}

The independent variables are the variables that affect or that cause the occurrence of the change. According to Sugiyono (2012, p. 59) independent variable is the variable that affect or be a cause of change in the dependent variable incidence or (variable). Independent variables used in this study is the Debt to Equity Ratio, Inventory Turn Over, and Total Assets Turn Over.

a) Debt to Equity Ratio

According to Cashmere (2012, p. 158) Debt to Equity Ratio is a ratio used to assess the debt with equity, this ratio is sought by way of compare between the entire debt includes debt smoothly with the rest of the equity. This ratio is useful to know the amount of funds that provided loans (lender) and the owner of the company.

b) Inventory Turn Over

According to Cashmere (2012, p. 180) inventory turnover ratio is used to measure the number of times the funding that was planted in stock (inventory) is spinning in one period. The smaller this ratio, the more is not good and vice versa.

c) Current Ratio 
According to Hery (2014, p. 152) Current Ratio is a ratio used to measure a company's ability to meet short-term obligations that are maturing soon using total assets smoothly. In other words, current ratio illustrates how big the number of availability of assets owned by the company smoothly compared to total obligations of lancer

\section{RESEARCH RESULTS}

\begin{tabular}{|c|c|c|c|c|c|}
\hline \multirow{2}{*}{ Model } & \multicolumn{2}{|c|}{$\begin{array}{c}\text { Unstandardized } \\
\text { Coefficients }\end{array}$} & $\begin{array}{c}\text { Standardized } \\
\text { Coefficients }\end{array}$ & t & Sig. \\
\cline { 2 - 3 } & $\mathrm{B}$ & Std. Error & Beta & & \\
\hline (Constant) & -6.882 & 8.652 & & -.795 & .432 \\
\hline Debt to Equity Ratio & -.104 & .065 & -.229 & -1.582 & .122 \\
\hline Inventory Turn Over & 1.931 & .735 & .260 & 2.628 & .013 \\
\hline Current Ratio & .052 & .015 & .511 & 3.446 & .001 \\
\hline
\end{tabular}

Tabel 1. Multiple Linear Regression Test Results

From table 1 it can be known values as follows:

$Y=-6.882+-\mathbf{- 0 . 1 0 4} X_{1}+\mathbf{1 . 9 3 1} X_{2}+0.052 X_{3}$

Description:

a) The value of the constants of 6,882. This shows that if the value of the Debt to Equity Ratio (X 1), Inventory Turn Over (X 2) and the Current Ratio (X 3) equal to zero (0), then the value of the Return On Equity (Y) will decrease of 6,882.

b) the regression coefficients $X$ 1) values of-0104 shows if the Debt to Equity Ratio (X 1) experienced an increase then will result in a decrease in the value of the Return On Equity (Y) the pharmaceutical sector Companies registration-0104 assuming that independent variable others are considered constant.

c) regression coefficients of X 2) value of 1,931 pointed out that if the Inventory Turn Over (X 2) has increased, it will result in an increase in the value of the Return On Equity (Y) companies of the pharmaceutical sector of 1,931 assuming independent variable others are considered constant. the regression coefficient Values d) X 3 of 0052 pointed out that if the Current Ratio (X 3) experienced an increase then will result in a decrease in the value of the Return On Equity (Y) companies of the pharmaceutical sector of 0052 assuming other independent variables considered to be constant.

To see the influence of the Debt to Equity Ratio, Inventory Turn Over Ratio and Current partially against the Return On Equity can be done using statistical tests t. With regard to the results of statistical tests $t$ obtained from SPSS version 20.00 is as follows:

\begin{tabular}{|c|c|c|c|c|c|}
\hline \multirow[t]{3}{*}{ Model } & \multirow{2}{*}{\multicolumn{2}{|c|}{\begin{tabular}{|l} 
Unstandardized \\
Coefficients
\end{tabular}}} & \multirow{3}{*}{\begin{tabular}{|l|} 
Standardized \\
Coefficients \\
Beta \\
\end{tabular}} & \multirow[t]{3}{*}{$t$} & \multirow[t]{3}{*}{ Sig. } \\
\hline & & & & & \\
\hline & $\mathrm{B}$ & Std. Error & & & \\
\hline \multirow{4}{*}{$\begin{array}{l}\frac{\text { (Constant) }}{\text { Debt to Equity Ratio }} \\
\underline{\text { Inventory Turn Over }} \\
\text { Current Ratio }\end{array}$} & -6.882 & 8.652 & & -.795 & .432 \\
\hline & -.104 & .065 & -.229 & -1.582 & .122 \\
\hline & $\underline{1.931}$ & .735 & .260 & 2.628 & .013 \\
\hline & .052 & .015 & .511 & $\overline{3.446}$ & .001 \\
\hline
\end{tabular}

Dependent Variable: Return On Equity

Table 2. The t-test results 
The influence of the Debt to Equity Ratio Towards Return On Equity calculation Of partially test the influence of the Debt to Equity Ratio against the Return On Equity amounted to thitung values obtained1,582 amounting ttabel while the value and significance of 2,026 $0122>0.05$ mean H0 is accepted (Ha was rejected). This shows that the Debt to Equity Ratio has no effect against a Return On Equity in Pharmaceutical Sector Companies were listed on the Indonesia stock exchange.

The Influence Of Inventory Turn Over Against The Return On Equity

Calculation of partially test the influence of Inventory Turn Over against the Return On Equity amounted to thitung value of 2,628 gained while 2,026 ttabel of significance and value of 0.05 means Ha $0.013<$ received ( $\mathrm{H0}$ is rejected). This shows that the Inventory Turn Over effect on Return On Equity in the pharmaceutical sector Companies were listed on the Indonesia stock exchange.

The Influence Of Current Ratio Against The Return On Equity

Calculation of partially test the influence of Current Ratio against the Return On Equity is obtained a value of thitung of 3,446 while the ttabel of the significance and value of 2,026 0.001 means Ha received $0.05<$ (H0 is rejected). This shows that the Current Ratio effect on Return On Equity in the pharmaceutical sector Companies were listed on the Indonesia stock exchange.

Tabel 3. Hasil Uji F

\begin{tabular}{|ll|l|l|l|l|l|}
\hline Model & & Sum of Squares & df & Mean Square & F & Sig. \\
\hline \multirow{2}{*}{1} & Regression & 5153.722 & 3 & 1717.907 & 27.861 & $.000^{\mathrm{b}}$ \\
& Residual & 2219.751 & 36 & 61.660 & & \\
& Total & 7373.473 & 39 & & &
\end{tabular}

a. Dependent Variable: Return On Equity

b. Predictors: (Constant), Current Ratio, Inventory Trurnover, Debt to Equity Ratio

Based on the results of testing simultaneously, then the value of Fhitung can be obtained with a significant level of 27,861 0000 while Ftabel of 2,870 with significant level of 0.05 . Based on these results it can be known that Fhitung > Ftabel $(27,861>2,870)$, this means the Ha received while H0 is rejected. So it can be concluded that the variable Debt to Equity Ratio, Inventory Turn Over Ratio and Current simultaneously effect significantly to Return On Equity on the pharmaceutical sector Companies were listed on the Indonesia stock exchange. To know so far where the percentage of contributions or the influence of Debt to Equity Ratio, Inventory Turn Over Ratio against and Current Return On Equity it can be known through the determination of the test as follows:

\section{Tabel 3. Results The Coefficient Of Determination}

\begin{tabular}{|c|c|c|c|}
\hline $\mathrm{R}$ & R Square & $\begin{array}{l}\text { Adjusted R } \\
\text { Square }\end{array}$ & $\begin{array}{l}\text { Std. Error of the Durbin-Watson } \\
\text { Estimate }\end{array}$ \\
\hline $.836^{\mathrm{a}}$ & .699 & .674 & 7.85237 \\
\hline
\end{tabular}

a. Predictors: (Constant), Current Ratio, Inventory Turn Over, Debt to Equity Ratio

b. Dependent Variable: Return On Equity

Based on table 3, indicates that the R-Square test using SPSS program version 20.00, then the test results can be known the coefficient of determination is as follows:

$$
\begin{aligned}
\mathrm{D} & =\mathrm{R} 2 \times 100 \% \\
\mathrm{D} & =0.699 \times 100 \% \\
& =69.9 \% \text { a value of R-Square value above } 0.699 \text { meaning shows that approximately }
\end{aligned}
$$

69.9\% variable (Y) Return On Equity can be explained by the variables (X 1) Debt to Equity Ratio (X 2) Inventory Turn Over (X 3) Current Ratio. Or it can be said that the contribution of the Debt to Equity Ratio, Inventory Turn Over Ratio against and Current Return On Equity on the pharmaceutical sector companies were listed on the Indonesia stock exchange namely amounting to $69.9 \%$. While the rest of $30.1 \%$ are affected by other variables not examined in this study. 


\section{DISCUSSION}

\section{The influence of the Debt to Equity Ratio against the Return On Equity}

The greater the total debt compared to equity total will show the greater dependency of the company towards outsiders. This will impact declining returns on capital (ROE) used to cover some or all of the debt - debt either short-term or long-term. According to Cashmere (2012, p. 158) the greater the ratio, the more unfortunate because it will be even greater risk borne over the failures that may occur in the company. Large debts will have an impact on financial risk which must be borne by the company or burdened with interest payments in large numbers.

But when the loans yield funds are used efficiently and effectively then this will provide a great opportunity for companies to increase profits. Based on the results of research conducted on the influence of the author's Debt to Equity Ratio against the Return On Equity in the pharmaceutical sector Companies were listed on the Indonesia stock exchange stating that thitung < ttabel IE-1,582 value 2,026 < significant of $0122>0.05$ where thitung resides in the acceptance of H0 so Ha was rejected. This shows that the Debt to Equity Ratio has no effect against a partially significant Return On Equity on the pharmaceutical sector companies were listed on the Indonesia stock exchange.

Results of research is certainly different from the results of research Hantono (2015) stating that the Debt to Equity Ratio has a significant influence towards Return On Equity, while in this study indicate that the Debt to Equity Ratio is not one of the factors that affect the Return On Equity. No significance on this variable could have been caused by other factors such as different research venues, tested different data, and the number of samples examined is also different from previous research. Then the authors can conclude that there is no kesesuain between results with theory and research. Namely, the absence of significant influence between the Debt to Equity Ratio against the Return On Equity.

\section{The influence of Inventory Turn Over against the Return On Equity}

The increasing Inventory Turn Over a company, then the faster return of funds that are embedded in the inventory. As a result, the profit obtained will be increased. The large number of profit earned will raise the level of profitability of the company. This means companies either in using ekuitinya to generate a profit. According to Cashmere (2012, p. 180) inventory turnover ratio is used to measure the number of times the funding that was planted in the inventory is spinning in one period. The inventory who managed and sold well certainly cash refund will speed up so that it can give an indication that the company is its efficiency in managing inventory. Based on the results of research undertaken researchers regarding the influence of Inventory Turn Over against the Return On Equity in Pharmaceutical sector companies were listed on the Indonesia stock exchange stating that thitung > tabel i.e. 2,628>2,026 with a value significant of 0.013 thitung which is $0.05<$ in the rejection of $\mathrm{HO}$ so Ha.

This shows that the Inventory Turn Over significant influential partially against the Return On Equity in the pharmaceutical sector Companies were listed on the Indonesia stock exchange. this same research results with the results of the research of Jufrizen (2015) that stated that the Inventory Turn Over have significant influence towards Return On Equity. In this research indicate that in Inventory can Turn Over is one of the factors that affect the Return On Equity. Then the authors can conclude that there is a kesesuain between results with theory and research. Namely, the existence of significant influence between the Inventory Turn Over against the Return On Equity.

\section{The influence of Current Ratio against the Return On Equity.}

The company is able to meet its assessed as a liquid. Quantity ratio is often regarded as a measure of good or satisfactory level of liquidity of a company. But when the number ratio too high then it means there are a lot of funds that are embedded in working capital that does not turn a profit.According to Munawir (2014, p. 73) Current Ratio is too high indicating an excess of cash money or other current assets compared with the present or the required level of liquidity is lower than current assets and vice versa. This excess will certainly lose the opportunity to obtain an advantage. It also shows the use of cash and short-term liabilities are not used efficiently. Based on the results of research undertaken researchers regarding the influence of 
Current Ratio against the Return On Equity in the pharmaceutical sector companies were listed on the Indonesia stock exchange stating that thitung $>$ ttabel i.e. 3,446 $>2,026$ with significant values of 0.001 is thitung where $0.05<$ in the rejection of $\mathrm{H} 0$ so Ha. This shows that the Current Ratio significantly influential partially against the Return On Equity in the pharmaceutical sector Companies were listed on the Indonesia stock exchange. This is the same research results research results Novianti (2015) which States that the Current Ratio has a significant influence against the Return On Equity. In this study may indicate that in the Current Ratio is one of the factors that affect the Return On Equity. Then the authors can conclude that there is a kesesuaian between results with theory and research. Namely, the existence of significant influence among the Current Ratio against the Return On Equity.

\section{The influence of the Debt to Equity Ratio, Inventory Turn Over Ratio Against and Current Return On Equity}

Various financial ratios can be calculated using the financial statements of the company. Return On Equity is a profitability ratio of part in analyzing the financial statements over the company's financial performance reports. The higher the Return On Equity shows the more efficient companies in managing their own capital to generate profits/net profit. Based on research undertaken researchers regarding the influence of the Debt to Equity Ratio, Inventory Turn Over Ratio against and Current Return On Equity on the pharmaceutical sector Companies were listed on the Indonesia stock exchange stating that retrieved the value Fhitung of significance value 0.000 27,861 whereas Ftabel of 2,870 with significant level of 0.05 . Based on these results it can be known that Fhitung > Ftabel $(27,861>2,870)$, this means the Ha received while H0 is rejected. So it can be concluded that the variable Debt to Equity Ratio, Inventory Turn Over Ratio and Current simultaneously effect significantly to Return On Equity on the pharmaceutical sector companies were listed on the Indonesia stock exchange.

\section{CONCLUSION}

1) Debt to Equity Ratio does not have significant influence towards Return On Equity. This shows that the company is capable of restoring the entire off her debts without reducing the benefits that will be returned to shareholders. No significance on this variable could have been caused by other factors such as different research venues, tested different data, and the number of samples examined is also different from previous research. However it should still be noticed because of the Debt to Equity Ratio is also important for lenders and investors before providing loans and capital to the company.

2) Inventory Turn Over have significant influence towards Return On Equity. This shows that the total sales or revenues belonging to the company's has contributions in improving and reducing the number of returns on capital (ROE). For it is this ratio needs to be payed in order not to be the cause of the occurrence of a decrease in the number of returns on capital (ROE).

3) Current Ratio has a significant influence against the Return On Equity. This shows that the total current assets owned by the company's has contributions in improving and reducing the number of returns on capital (ROE). Thus this ratio needs to be known and well managed to produce the best.

4) Debt to Equity Ratio, Inventory Turn Over, and Current Ratio simultaneously have significant influence towards Return On Equity. This shows that a third of the free variables examined the author's has contributions in influencing the amount of the repayment of capital (ROE) company. So the process researchers to know these results can serve as knowledge in studying science was studied during the following activities and associated costs. 


\section{REFERENCES}

Arikunto, Suharsimi. 2006. Research Procedures: an approach to practice. (Revised Edition). Jakarta: Pt. Rineka Copyright.

Arwana, Bambang. 2009. Basic Purchases company (4th Edition). Yogyakarta: Yogyakarta-BPFE Publishers.

Azuar Juliandi, Irfan. 2014. Business Research Methodology. (First Printing) Umsu Press Publisher.

Brigham, e. F, J Houston, f. 2012. Basics of financial management (11th Edition) Salemba Jakarta: four Translation Of Ali Akbar Yulianto.

Fahmi, Irham. 2015. Introduction to financial management. (The Fourth Mold). Bandung: Alfabeta CV. Ghozali, Imam. 2007. The application of Multivariate Analysis With SPSS Program. (The Fourth Mold) Semarang Is Diponegoro University Publisher: BP.

Hani, Syafrida. 2015. Engineering analysis of the financial statements. Penertbit Umsu Press.

Hantono. 2015. The influence of Current Ratio And Debt to Equity Ratio Towards Profitability in the Metal sector of manufacturing companies and the like are listed on the Indonesia stock exchange Period 2009-2013. Journal. University Of Indonesia Prima.

Hery. 2014. Analysis of Performance management. (First Printing). Jakarta: Grasindo PT.

Hery. 2015. Introduction to Accounting Comprehensive Edition. (First Printing). Jakarta: Grasindo PT.

Cashmere. 2012. Analysis of financial statements. (The Fifth Mould). Jakarta: PT RajaGrafindo Persada Publisher.

Jufrizen. 2015. The influence of Inventory and Fixed Assets Turn Over Turn Over against the Return On Equity At the pharmaceutical company listed in BEI 2007-2013 Year. Journal. Muhammadiyah University Of North Sumatra.

Munawir. 2014. analysis of financial statements. (Fourth Edition). Yogyakarta: Liberty.

Novianti. 2015. The influence of Current Ratio, Growth Of Sales, Working Capital Turnover, and Debt To Equity.

Sofyan Harahap, Syafri. 2015. Critical analysis of financial statements (the twelfth Prints). Jakarta: PT Raja Grafindo Persada.

Sudana, BPFE I Made. 2011. The company's Financial Management Theory Practice \&. Publisher Eason.

Sugiyono. 2008. The qualitative and quantitative research Methods $R \& D$ (Prints the fifth). Bandung Alfabeta CV.

Syamsuddin, Lukman. 2009. The company's Financial Management. (New Edition). Jakarta: PT RajaGrafindo Persada Publisher.

Tsing Agus. 2010. Financial management, theory and applications. (Fourth Edition). Yogyakarta: Yogyakarta. 